Рекомендована д. фармац. наук, проф. Д. І. Дмитрієвським

УДК 615.01.47:615.454:339.138

\title{
MARKET ANALYSIS OF SEMISOLID DOSAGE FORMS REGISTERED IN UKRAINE AND RESEARCH OF EXCIPIENTS INCLUDED TO THEIR FORMULAS
}

\author{
(ㄱ) B. Vons, M. B. Chubka, T. A. Groshovyi \\ Ternopil State Medical University by I. Ya. Horbachevsky
}

\begin{abstract}
Summary: it has been investigated the domestic market of semisolid dosage forms registered in Ukraine. Excipients as a part of various semisolid dosage forms have been studied. It has been found that semisolid dosage forms include basic substrate, emulsifiers, gelling agents, solvents, antimicrobial preservatives, antioxidants, solubilizers, colorants, flavors, stabilizers $\mathrm{pH}$ and thickeners.
\end{abstract}

Key words: semisolid dosage forms, analysis of pharmaceutical market, excipients.

Introduction. Nowadays, semisolid dosage forms (SDF) take the fifth range among the other dosage forms that are registered in Ukraine [1] as well as the main position among medications (M) of local therapy for treatment of dermatological diseases [2]. After analyzing the list of medications approved in Ukraine, which are available without prescription from pharmacies and their departments, agreed by the order of Ministry of Health of Ukraine No. 166 dated on 26.02.2013, a group of authors has found that the SDF cover about $12 \%$ of all medications, including $58 \%$ of semisolid medication (SM) could be sold without prescription [2]. SDF for external use is produced for local action or transdermal support of active ingredients, for softening or protective action. Now people use SDF to the skin not only for treatment of dermatological diseases, but also for regular treatment due to the lower risk of systemic side effects compared with parenteral and oral medications. They are widely used in such fields of medicine as dermatology, surgery, ophthalmology, urology, dentistry, etc. [3].

SDF are divided into gels, pastes, liniments, creams, ointments according to the order of Ministry of Health of Ukraine No. 235 dated on 26.06.2002, the "Classification of medications" [4].
SM for external use are divided into ointments, creams, gels, pastes, poultices, medical plasters, skin blisters and liniments according to the pharmacopeia classification [5]. SM usually contain active substances and excipients (E) which should be in equal parts in the medication. Excipients $(E)$ form simple or complex basis that can produced independently or can be got in the manufacturing process of SM. The basis depending on its composition can affect to the release, bioavailability and therapeutic effect of the medication. The list of excipients (E) that can be used for the production of medications in Ukraine is regulated by the Ministry of Health of Ukraine by the order dated on 19.06.2007, No.339 and includes 38586 excipients (E) and colorants [6].

The aim was to research the domestic market of SDF and study the range of excipients (E) that are included to the medications registered in Ukraine.

Research methods. The object of the study was the information concerning SDF registered in Ukraine as of date of 01.09.2014 on the site "Legal and guiding documents of Ministry of Health of Ukraine" [7]. Methods of statistical analysis were used to process the obtained data.

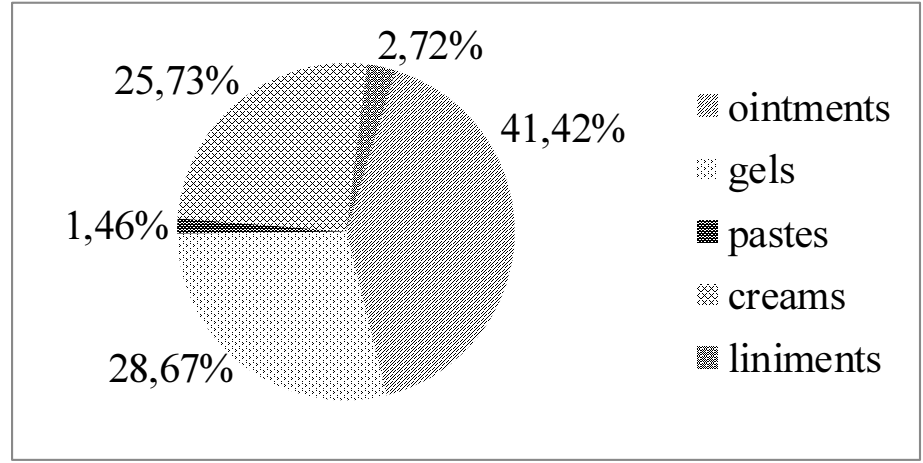

Fig. 1. Distribution diagram of SDF due to the type of medication registered SM

ISSN 2312-0967. Pharmaceutical review. 2015. № 1 
Фармацевтичний менеджмент, маркетинг та логістика

Pharmaceutical management, marketing and logistics

\section{Results and discussion.}

There were registered 478 names of SDF in Ukraine as for the date of September 01, 2014. They include: gels $-28,67 \%$, liniments $-2,72 \%$, ointments - 41,42 \%, creams- 25,73\%, pastes - 1,46 \% (Fig. 1).

The domestic market depends on import, because foreign SM occupy $65.27 \%$ of range (312 items), while domestic production of SM has only $34.73 \%$ of the market (166 items) (Fig. 2).

SDF on the Ukrainian market are represented by 37 countries, Germany is the leader - 73 medications (M) (23.39 \%), India - medications (M) (18.91\%), Poland - 26 (8.33\%), Russia - 14 (4.48 $\%)$ and Italy - 12 (3.84\%). Other countries import no more than 10 products and occupy $41.02 \%$ of the market of SDF in Ukraine.

SM are produced by 18 pharmaceutical enterprises in Ukraine of different ownership forms, mostly appeared in the domestic pharmaceutical industry for the last 15 years. JSC Fitofarm (Artemivsk, Donetsk region) and JSC Lubnyfarm (Lubny, Poltava region) take the leading positions due to the production of SDF (Fig. 3).

$\mathrm{SM}$ is used to treat various diseases, in particular, they are often used in dermatology (47.28\% SDF), rheumatology (18.62 \% SDF), surgery (18.20\% SDF) and a list of medications in ophthalmology, otolaryngology, proctology, gynecology of used SDF is insignificant (Fig. 4).

However, despite of the popularity of using different types of SDF, their use in various fields of medicine is not identical. For example, dermatological and rheumatic diseases are treated almost with all SM and the range of SDF used in pharmacotherapy of ophthalmic and ENT diseases are limited to ointments and gels (Table 1).

An important feature of SDF is the presence of a large number of excipients (E), namely: bases and its components, solvents, stabilizers, emulsifiers (direct emulsion and inverse emulsion), regulators $\mathrm{pH}$, solubilizers, gelling agents, preservatives and other excipients.

The choice of excipients (E), their rational use and combination among each other are important parts of pharmaceutical development as medications in general, and especifically SM [8-10].

At this stage of the study, excipients (E) which are registered as a part of all SDF (ointments, lotions, liniments, pastes, gels) have been analyzed. All excipients were grouped by functional and technological features.

The instructions for medical use of medications should include a list of active pharmaceutical ingredients (API) and excipients, except doses and guidelines for indications advantages and disadvantages the medication. However, the analysis of the electronic version of the site "Legal and guiding documents of Ministry of Health of Ukraine" showed that in some cases the list of excipients is not presented, that's why these medications are not studied and are not included with the statistics. The list of all excipient groups are presented in Table 2.

Formative substances for SM technology are basics selected considering physicochemical and pharmacological properties of API, speed of their

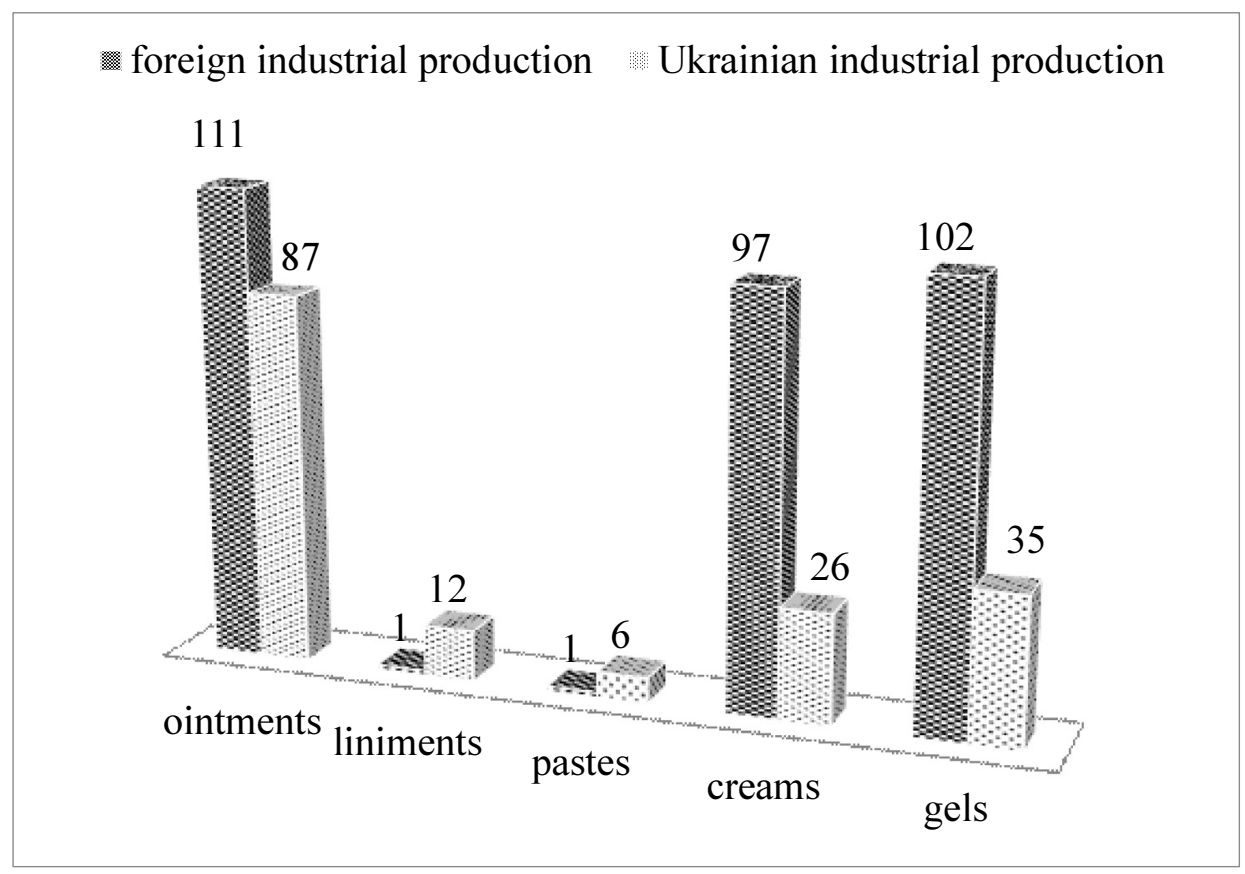

Fig. 2. Distribution of SDF due to their manufaturers

ISSN 2312-0967. Фармацевтичний часопис. 2015. № 1 
Фармацевтичний менеджмент, маркетинг та логістика

Pharmaceutical management, marketing and logistics

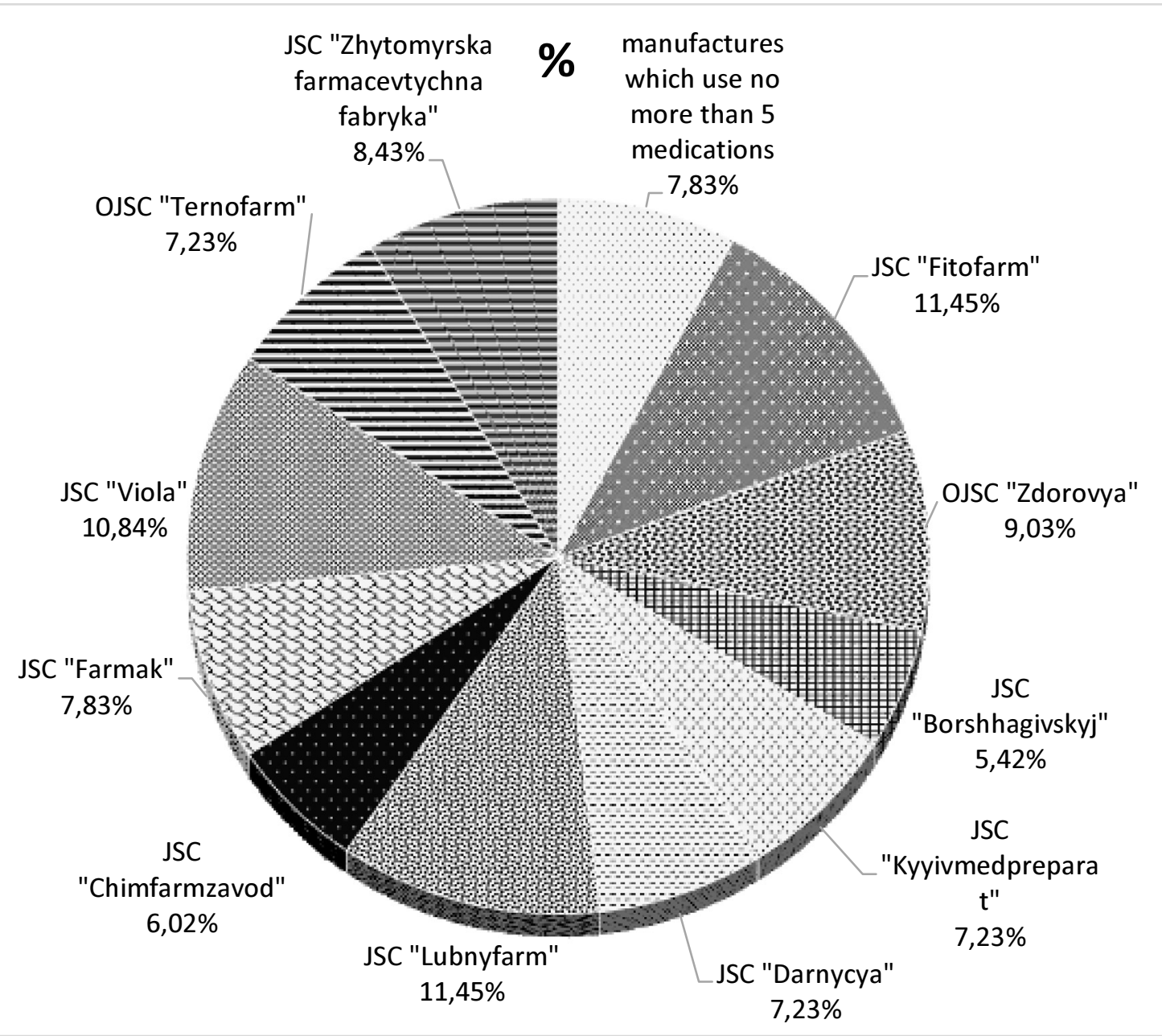

Fig. 3. Distribution of domestic SDF due to the manufacturing company

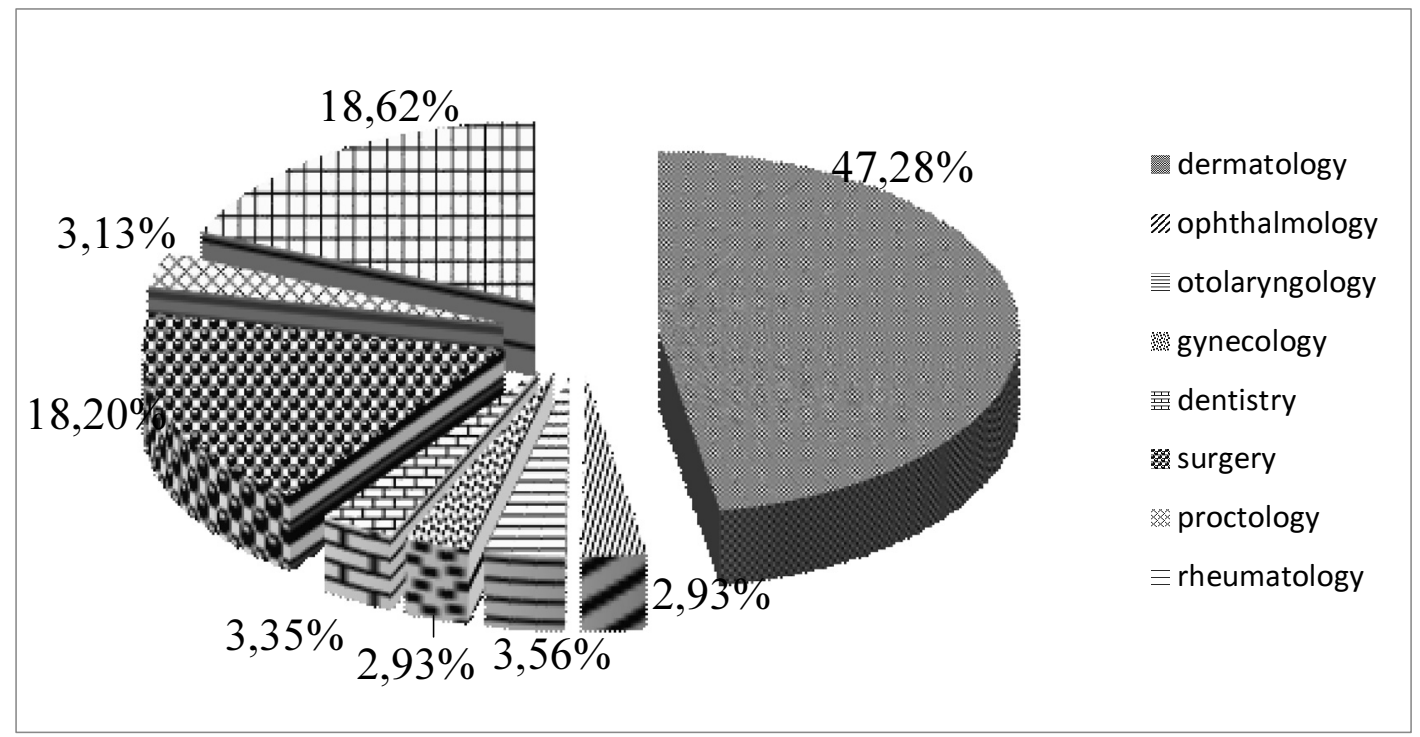

Fig. 4. Balance of SDF for use in various fields of medicine

ISSN 2312-0967. Pharmaceutical review. 2015. № 1 
Фармацевтичний менеджмент, маркетинг та логістика

Pharmaceutical management, marketing and logistics

Table 1. Distribution on different SDF due to their use in various fields of the medicine

\begin{tabular}{|c|c|c|c|c|c|c|}
\hline Field of medicine & ointments & liniments & gels & pastes & creams & Total number \\
\hline dermatology & 98 & - & 26 & 4 & 98 & 226 \\
\hline otolaryngology & 11 & - & 3 & - & - & 14 \\
\hline surgery & 38 & 11 & 25 & 3 & 10 & 87 \\
\hline proctology & 9 & - & 3 & - & 3 & 15 \\
\hline ophthalmology & 13 & - & 4 & - & - & 17 \\
\hline gynecology & - & - & 7 & - & 7 & 14 \\
\hline dentistry & 2 & - & 14 & - & - & 16 \\
\hline rheumatology & 27 & 2 & 55 & - & 5 & 89 \\
\hline Total & 198 & 13 & 137 & 7 & 123 & 478 \\
\hline
\end{tabular}

Table 2. The list of all excipient groups which are used for manufacturing SDF.

\begin{tabular}{|c|l|c|c|c|c|c|}
\hline \multirow{2}{*}{ No. } & \multicolumn{1}{|c|}{ Excipient groups } & \multicolumn{5}{c|}{ Quantity of items in this group } \\
\cline { 3 - 7 } & & ointments & liniments & creams & pastes & gels \\
\hline 1 & direct emulsion & 34 & - & 112 & 2 & 25 \\
\hline 2 & inverse emulsion & 39 & 5 & 87 & 1 & 7 \\
\hline 3 & $\begin{array}{l}\text { solubilizers (hydrophobic, } \\
\text { hydrophilic) }\end{array}$ & 99 & 5 & 160 & 2 & 188 \\
\hline 4 & $\begin{array}{l}\text { substances that increase the } \\
\text { melting point and viscosity basics }\end{array}$ & 185 & - & 127 & 1 & 8 \\
\hline 5 & gelling agents & 16 & 2 & 19 & 2 & 127 \\
\hline 6 & antimicrobial preservatives & 63 & 3 & 144 & 5 & 143 \\
\hline 7 & antioxidants & 30 & 1 & 77 & 3 & 68 \\
\hline 8 & solubilizers & 1 & - & & - & 2 \\
\hline 9 & colorants & 3 & - & 4 & 2 & 4 \\
\hline 10 & flavors & 21 & - & 13 & 6 & 76 \\
\hline 11 & stabilizers pH & 23 & 7 & 90 & & - \\
\hline 12 & stabilizers and thickeners & 13 & 1 & & - & 41 \\
\hline
\end{tabular}

release, absorption and nature of their act, and also DF technology. Due to the ability to interact with the water, the basics are divided into hydrophilic, hydrophobic (lipophilic) and diphilic (hydrophiliclipophilic) [11, 12].

Hydrophilic basics substrate as gels polyethylene glycols (polyethylene oxide), gel polysaccharides (cellulose derivatives - sodium carboxymethylcellulose, sodium carmellose, methylcellulose), copolymers of acrylic acid gel (carbomer makes 974P, 934P, 940, 980 (synonym "carbopol")) proksanol basics (known as "poloxamers," "hidropol"), gelatin, glycerin, and etc. are often used for the SM technology registered in Ukraine. Nowadays, poloxamers are of different makers, bifunctional polymers, which molecules have hydrophobic central part and two hydrophilic finishes, are popular among manufacturers. These compounds do not have irritating and sensitizing actions compatible with almost all API except phenols and amino acids [13, 14].

Carbomer - cross-copolymers based on polyacrylic acid. The optimum $\mathrm{pH}$ for the preparation of the gel is based on carbomer range from 5 to 8 , with the formation of transparent gels or with only a slight opalescence. While studying the possibility of using a part of carbomer gels, keep in mind the type of carbomer, nature alkaline component for the composition of dispersed environment, the relations between carbomer and alkali, which depend on the rheological parameters and $\mathrm{pH}$ gel. Rheological features of gels are practically independent of temperature, gel-like consistency of medications can be saved even at high temperatures. Gels and creams form a protective and moisturizing patch in Carbopol. Currently features of gel polymers which are analogous of carbomer, including "Arespol”, "Ultrez 10", "Carbopol 2020, 2001" of Russian, Belgian and German manufacturing are actively studied [9, 15-17].

Collagen, chitosan and bentonite basics are used only in some formulas of SM.

Fat, carbohydrate and silicone basics are included to the group of lipophilic basics. Among the fat basics for SM are commonly used fat pork, almond oil, corn, peach, peanut. The undisputed

ISSN 2312-0967. Фармацевтичний часопис. 2015. № 1 
leader in hydrocarbon basics are vaseline, moreover, to the semisolid forms are included wax, mineral wax, ceresin and vaseline oil.

To diphilic basics are included absorptial hydrophilic and hydrophilic, direct and inverse emulsion basics.

Alginic acid and its salts, carbomer, cellulose derivatives, proksanol PEG 1500-8000, aerosil, gelatin etc. are used for the formula of SDF among gelling agents.

It was analyzed that the most represented SM in the pharmaceutical market are emulsions, for which formation requires the use of emulsifiers of direct and inverse emulsions that form and increase the stability of emulsions.

Surfactants (S) stabilize ointments, liniments, creams, gels and pastes, increasing their stability by lowering the surface tension at the interface of two liquid phases. The choice of surfactants is done taking into the consideration the magnitude of its hydrophilic-lipophilic balance (HLB). Often, in order to obtain a specific pharmacological effect and maximum resistance DF it can be used several emulsifiers with different HLB values. To stabilize the direct emulsion, HLB emulsifiers are used less than 10 , and for the inverse emulsion, HLB value should be greater than 10 [12].

Pharmaceutical manufacturers most commonly use emulsifiers such as fatty alcohols and their derivatives (e.g. emulsion wax), high-cyclic alcohols and their derivatives (often found cholesterol), partial esters of sorbitan and fatty acids, known as - span (synonym "alatsel") for the formation of direct emulsion.

There are different types of span under different names, which have different acid and came in response esterification of sorbitan, for example, Sorbitani lauras, Sorbitani oleas, Sorbitani palmitas, Sorbitani sesquioleas, Sorbitani trioleas [18-20] in European, British Pharmacopoeia and US Pharmacopoeia.

There are ionic and nonionic surfactants among inverse emulsions. Anion-active emulsifiers of this kind can be soaps and alkyl sulfates. Polysorbates (synonymous "tween"), which are polyoxyethylene sorbitan monolaurate esters and higher fatty acids are mostly used among the emulsifiers of such type. Tweens can be of various types with different acids, which came in esterification, for example tween20 based on lauric acid, tween-40 based on palmitic acid, tween-60 and tween-80 based on stearic and oleic acid respectively [11, 15].

Purified water, non-aqueous hydrophilic solvents (e.g. ethanol, glycerol, PEG-400, etc.), non-aqueous solvents hydrophobic (e.g. Vaseline, benzyl benzoate, fish oil, etc.) are included to the liquids used in the manufacture SM [11]. To improve the dispersion of medications in heterogeneous systems can be used ethanol, glycerol, propylene glycol, dimeksid and other solvents. These excipients (E) accelerate and improve the dissolution API, comparing to water, they have greater lipophilicity and improve conversion of API through biological membranes. Polyethylene glycol stabilizes the semisolid form of molecules by preventing the interaction between $\mathrm{API}$ and excipients (E). Substances that enhance absorption (Cetyl palmitate, cetyl alcohol, ethyl alcohol) increase the penetration of substances through the skin.

In developing the SDF it should be paid attention to the excipients $(E)$, which can change the physical and chemical properties of medication. Such substances are antioxidants, antimicrobial preservatives, surfactants, solvents [10].

Antimicrobial preservatives are used only in extreme cases where it is impossible to use other to ensure the sterility of the medication through a complex physical and chemical structure of API, when sterilization is not possible because of recent or inability to use one dose containers. Preservatives should guarantee the sterility of dosage form for the whole period of their use that means to have reliable antimicrobial preservatives, be compatible with other API and excipients. As an example of incompatibility, which has the result of precipitation and reduce antimicrobial action, may be commonly use the carbomer and benzalkonium chloride for gels [9-10, 21-22].

From the right choice of preservatives depends not only the quality of medications, but also safety, related to safety of the preservatives. Under the instruction 42-3.6:2004, for each antioxidant and antimicrobial preservative, the information in the registration dossier should include the following: a) the reason for inclusion; b) evidence of effectiveness; c) the control method for the ready product; d) details of the labeling of ready products; e) information about safety $[10,21]$.

Today, the range of antimicrobial preservatives that are approved for use is wide enough, but developing SDF manufacturers prefer parabens (nipahin, nipazol), benzoic acid and its salts, sorbic acid and its salts [12, 22].

The concentration of preservative should be based on terms of efficacy and safety to use minimum concentration, which provides the necessary level of efficiency. The appropriate test for determining the effectiveness of antimicrobial preservative is a test "5.1.3. The effectiveness of antimicrobial preservatives" described in the European Pharmacopoeia and SPU [18, 23].

The most common antioxidants using by modern pharmaceutical manufacturers in SDF is ascorbic acid and its salts, б-tocopherol, disodium edetate,

ISSN 2312-0967. Pharmaceutical review. 2015. № 1 
Фармацевтичний менеджмент, маркетинг та логістика Pharmaceutical management, marketing and logistics

butylated hydroxyanisole and Butylated hydroxytoluene, sodium metabisulfite.

Antioxidants are included to the part of medications only in that cases where it is proved that their use is mandatory. In the case of reducing the possibility of passing oxidative processes in a preparation by optimizing the production process, the feasibility of using antioxidants is not proved [10, 21].

To provide SDF an appropriate form and flavor, colorants and flavors are added to their composition; sugar substitutes, such as aspartame, sucrose, sucrose cocoate, saccharin and its salts, cyclamate are added to SM which are used in dentistry.

Substances of plant origin (essential oils of peppermint, orange, pine needles, cloves, alcoho extracts of medicinal plants) and synthetic substances, flavorings (menthol, vanillin, thymol) are used for better smell and taste.

\section{References}

1. Huryieva S. M. The research of excipients (E) which are used in semisolid medication registered at the territory of Ukraine. Note 1 / S. M. Huryieva, O. I. Lukashiv, T. A. Groshovyi // Pharmaceutical Journal. - 2012. - No. 4. - P. 178-183.

2. Popovych V. P. A pharmaceutical market of semisolid dosage forms / V. P. Popovych, O. M. Hlyshchenko, S. L. Khomenko // Pharmaceutical Journal. - 2013. No. 4. - P. 68-71.

3. Dermatological and transdermal formulations / Edited by Kenneth A. Waiters. - New York - London. - 2007. - 565 p. 4. Order of Ministry of Health of Ukraine dated on 26.06.2002 No. 235 On approving the Classificatory of medication formulas.

5. State Pharmacopoeia of Ukraine / State Enterprise, Ukrainian scientific Pharmacopoeia center of medication quality. $-1^{\text {st }}$ ed. - Completed 3. - Kharkiv: State Enterprise, Ukrainian scientific Pharmacopoeia center of medication quality, 2009. $-280 \mathrm{p}$.

6. Order of Ministry of Health of Ukraine dated on 19.06.2007 No. 339 On approving of the list of excipients and colorants included to the medication formulas.

7. Normative and guiding documents of Ministry of Health of Ukraine [electronic source] / Ministry of Health of Ukraine. - This information is available on: http. :// mozdocs.kiev.ua/

8. Instruction CT-H MO3У 42-3.0:2011. - Medications. Drug development (ICH Q8) / M. Liapunov, O. Bezugla, O. Soloviov [an others] // Standardization of pharmaceutical products. - Kyiv, Ministry of Health of Ukraine, 2012. - P. 519-544.

9. Semisolid dosage forms: Drug development and technology transfer / N. A. Liapunov, E. P. Bezugla, I. A. Zinchenko [and others] // Pharmaceutical branch. 2014. - No.5 (46). - P. 22-33.

10. Bilous S.B. Current issues on drug development of semisolid dosage forms for external use / S. B. Bilous,
Among all registered SDF, colorants are only in formula of 13 medications. Substances of copper complex of chlorophyll (E 141), titanium dioxide ( $E$ 171), blue colorant (E 133), tartrazine (E 102), quinoline yellow (E 104), carmoisine (E 122) are the most widely represented in this group.

Conclusions: 1. It was examined the range of SDF registered at the territory of Ukraine (478 medications, and 41,42\% are ointments).

2. SM were analyzed due to the fields of their use and manufacture, it was concluded the range increasing of ready SDF of domestic manufacture, because some medications of foreign manufacturing do not have counterparts in domestic manufacture.

4. The list of excipients (E) was investigated, as a part of ointments, creams, gels, pastes, liniments emulsifiers, basics, substances that increase the melting temperature, solvents, antimicrobial preservatives, flavorings and colorants.

T. G. Kalyniuk, N. I. Gudz // Pharmaceutical Journal - 2010. - No.2. - P. 17-27.

11. Excipients for medication technology: impact on technology, consumer, economic features and therapeutic effectiveness: textbook for student of higher educational pharmaceutical establishments / authors: I. M. Pertsev, D. I. Dmytriievskyi, V. D. Rybachuk and others; editor: I. M. Pertseva. - Kh.: Zoloti storinky, 2010. - 600 p.

12. Excipients used for technology of semisolid dosage forms (ointments, gels, liniments, creams) / O. A. Semkina, M. A. Dzavakhaian, T. A. Levchuk [and others] // Chemical and pharmaceutical journal. - No.9, Vol. 39. - P. 45-48. 13. PLGA poloxamer and PLGA:poloxamine blend nanoparticles: new carriers for gene delivery / N. Csaba, P. Caamaro, A. Sanchez [et al.] // Biomacromolecules. 2005. - No. 6. - P. 56-61.

14. Poloxamers as new kind of excipients / N. A. Shatova, E. P. Moskaleva, S. V. Kotelevtseva [and others] // development and registration of medication. - 2013. No. 5. - P. 37-42.

15. Handbook of Pharmaceutical Excipiets / Edit by R. C. Rowe, P. J. Sheskey, S. C. Owen. - London Chicago. -2006. - $560 \mathrm{p}$.

16. Influence of some solvents and carbomer to gels features / M. O. Liapunov, N. V. Volovyk, O. P. Bezugla [and others] // Farmakom. - 2003. - No. 3. - P. 55-61. 17. Polovlo N. P. Research of features of poly ethylene oxide carbomer gels / N. P. Polovko, O. G. Bashura // Ukrainian journal of clinical and laboratory medicine. 2010. No. 1, Vol. 5. - P. 46-48.

18. European Pharmacopoeia. $8^{\text {th }}$ Edition. - European Directorate for the Quality of Medicines (EDQM). - Council of Europe, 67075 Strasbourg Cedex, France 2013. $3655 \mathrm{p}$.

19. British Pharmacopoeia. - 2001. - Vol. 1,2. - 2639 p. 20. US Pharmacopoeia [electronic source] - 1 electronic optical disc, 2007.

ISSN 2312-0967. Фармацевтичний часопис. 2015. № 1 
Фармацевтичний менеджмент, маркетинг та логістика

Pharmaceutical management, marketing and logistics

21. Instruction 42-3.6:2004. - Instruction on quality. Medication. Excipients. - K., 2004. - 9 p.

22. Antimicrobial preservatives in the formula of manufactured medications / N. A. Liapunov, E. G. Zhemerova, E. p. Bezugla [and others] // Pharmacy. - 2004. - No.1. - P. 13-15.
23. State Pharmacopoeia of Ukraine / State Enterprise, Ukrainian scientific Pharmacopoeia center of medication quality. $-1^{\text {st }}$ ed. - Completed 4. - Kharkiv: State Enterprise, Ukrainian scientific Pharmacopoeia center of medication. 2011. - 540 p.

\section{АНАЛІЗ РИНКУ М'ЯКИХ ЛІКАРСЬКИХ ФОРМ, ЗАРЕЄСТРОВАНИХ В УКРАЇНІ, ТА ДОСЛІДЖЕННЯ АСОРТИМЕНТУ ДОПОМІЖНИХ РЕЧОВИН, ЩО ВХОДЯТЬ ДО ЇХ СКЛАДУ}

\section{Б. В. Вонс, М. Б. Чубка, Т. А. Грошовий}

Тернопільський державний медичний університет імені І. Я. Горбачевського

Резюме: досліджено вітчизняний ринок м'яких лікарських засобів, що зареєстровані в Україні. Вивчено асортимент допоміжних речовин, які входять до складу різних м'яких лікарських форм. Встановлено, що до складу м'яких лікарських засобів входять основи-носії, емульгатори, гелеутворювачі, розчинники, антимікробні консерванти, антиоксиданти, солюбілізатори, барвники, ароматизатори, стабілізатори рН і загусники.

Ключові слова: м'які лікарські форми, аналіз фармацевтичного ринку, допоміжні речовини.

\section{АНАЛИЗ РЫНКА МЯГКИХ ЛЕКАРСТВЕННЫХ ФОРМ, ЗАРЕГИСТРИРОВАННЫХ В УКРАИНЕ, И ИССЛЕДОВАНИЯ АССОРТИМЕНТА ВСПОМОГАТЕЛЬНЫХ ВЕЩЕСТВ, ВХОДЯЩИХ В ИХ СОСТАВ}

\section{Б. В. Вонс, М. Б. Чубка, Т. А. Грошовый}

Тернопольский государственный медицинский университет имени И. Я. Горбачевского МЗ Украины

Резюме: исследовано отечественный рынок мягких лекарственных средств, зарегистрированных в Украине. Изучен ассортимент вспомогательных веществ, входящих в состав различных мягких лекарственных форм. Установлено, что в составах мягких лекарственных средств используют основы-носители, эмульгаторы, гелеобразователи, растворители, антимикробные консерванты, антиоксиданты, солюбилизаторы, красители, ароматизаторы, стабилизаторы рН и загустители.

Ключевые слова: мягкие лекарственные формы, анализ фармацевтического рынка, вспомогательные вещества.

Отримано 12.03.2015

ISSN 2312-0967. Pharmaceutical review. 2015. № 1 